\title{
Gejala Klinis dan Pemeriksaan Penunjang pada Neonatus Terinfeksi COVID-19
}

\author{
Jason Rampengan, ${ }^{1}$ Johnny Rompis, ${ }^{2}$ Valentine Umboh ${ }^{2}$
}

\author{
${ }^{1}$ Program Studi Pendidikan Dokter Fakultas Kedokteran Universitas Sam Ratulangi, Manado, \\ Sulawesi Utara, Indonesia \\ ${ }^{2}$ Bagian Ilmu Kesehatan Anak Fakultas Kedokteran Universitas Sam Ratulangi, Manado, \\ Sulawesi Utara, Indonesia \\ E-mail: jasoncaesar7777.jc@gmail.com
}

\begin{abstract}
COVID-19 is spreading at an extremely rapid rate and can affect all age groups, albeit, information about clinical symptoms and laboratory examinations of COVID-19 I in neonates is still quite limited. This study was aimed to determine the clinical symptoms, radiographic examinations especially CT-scans, and laboratory tests that could appear in neonates suffering from COVID-19. This was a literature review study using three databases, namely Pubmed, Clinical Key, and Google Scholar. The keywords used were Covid-19 / SARS-CoV-2 AND Neonatus AND sign and symptoms AND laboratory. The selection based on inclusion and exclusion criteria, obtained 15 case report studies, three retrospective studies, one observational study, and one cohort study. The review revealed that the most frequent clinical features that appeared were fever (54.8\%), dyspnoea (35.4\%), and cough (29\%). Meanwhile, for CT-Scan radiographs, there were 14 of 31 neonates $(45.2 \%)$ did not show any abnormalities or normal. The most frequent abnormal image was ground glass opacity (GGO) (29\%). Among laboratory examinations, lymphopenia was the most common abnormality (32.2\%). Moreover, leukocytosis, leukopenia, thrombocytopenia, increased PCT, AST, etc. could also occur. Of all the reviewed literatures, there were no death cases of neonates died due to COVID-19. In conclusion, fever, dyspnea, cough, and lymphopenia are the most common findings as well as GGO in the CT-Scan radiograph.
\end{abstract}

Keywords: COVID-19, neonates

\begin{abstract}
Abstrak: COVID-19 menyebar dengan sangat pesat dan dapat menjangkiti semua kelompok usia namun informasi mengenai gejala klinis dan pemeriksaan laboratorium terhadap kelompok neonatus masih terbatas. Penelitian ini bertujuan untuk mengetahui gambaran klinis, pemeriksaan radiografi khususnya CT-Scan, dan pemeriksaan laboratorium yang bisa muncul pada neonatus dengan COVID-19. Jenis penelitian ialah literature review dengan pencarian data menggunakan tiga database yaitu Pubmed, Clinical Key, dan Google Scholar. Kata kunci yang digunakan yaitu Covid-19/ SARS-CoV-2 AND Neonatus AND sign and symptom AND laboratory. Hasil seleksi berdasarkan kriteria inklusi dan ekslusi mendapatkan 15 penelitian case report, tiga retrospective study, satu observational study, dan satu cohort study. Hasil kajian menunjukkan bahwa gambaran klinis yang paling sering muncul ialah demam $(54,8 \%)$, sesak $(35,4 \%)$, dan batuk (29\%). Pemeriksaan radiografi CT-Scan, neonatus yang tidak menunjukkan kelainan (normal) terdapat pada 14 dari 31 neonatus diamati $(45,2 \%)$, sedangkan kelainan yang sering muncul ialah ground glass opacity/GGO (29\%). Pada pemeriksaan laboratorium, limfopenia merupakan kelainan tersering (32,2\%), sedangkan leukositosis, leukopenia, trombositopenia, peningkatan PCT, AST, dll juga bisa terjadi. Dari semua literatur yang dikaji, tidak ditemukan kasus kematian neonatus akibat COVID-19. Simpulan penelitian ini ialah gambaran klinis yang paling sering muncul pada neonatus ialah demam, sesak, dan batuk, limfopenia, dan GGO pada CT-Scan.
\end{abstract}

Kata kunci: COVID-19, neonatus 


\section{PENDAHULUAN}

Corona virus disease 2019 adalah sebuah penyakit yang bermula pada Desember 2019 yang berasal dari Provinsi Wuhan, China. COVID-19, disebabkan oleh virus SARS-CoV-2 yang merupakan virus yang bisa menular kepada manusia ataupun hewan. Virus ini memiliki beberapa golongan, diketahui gejala awal dari manusia yang sudah terinfeksi dengan virus ini adalah infeksi saluran nafas berupa batuk atau pilek. Sampai sekarang, golongan virus ini sudah pernah menyebabkan pandemi di dunia yaitu pandemi virus Severe Acute Respiratory Syndrome (SARS) dan Middle East Respiratory Syndrome (MERS). ${ }^{1}$

Novel corona virus, SARS-CoV-2 (COVID-19) ialah pandemi virus yang sudah menghebohkan seluruh dunia karena kasus penyebarannya yang tergolong sangat cepat. Data terakhir menunjukkan bahwa virus ini telah menginfeksi kira-kira 31,2 juta penduduk dan telah memakan korban hampir 965 ribu orang di seluruh dunia. Berdasarkan laporan jumlah kasus yang di update secara terus menerus oleh World Health Organization (WHO), negara yang paling banyak penduduknya terjangkit dengan virus COVID-19 ialah Amerika Serikat dengan 6,86 juta penduduk dan meninggal sebanyak 202 ribu orang. Indonesia sendiri berada di peringkat ke-23 sebagai salah satu negara penyumbang total kasus virus COVID-19 pada penduduknya dengan total kira-kira 249 ribu orang yang terjangkit dan jumlah kematian mencapai sekitar 9.600 jiwa. $^{2}$

COVID-19 atau Severe Acute Respiratory Syndrome Coronavirus 2 (SARS-CoV2) adalah virus yang menyerang sistem pernapasan. Virus SARS-CoV-2 bisa menyebar melalui dua cara yaitu secara langsung melalui droplet, human-to-human transmission atau melalui kontak tidak langsung dengan objek yang terkontaminasi ataupun kontaminasi melalui udara. Seperti disebutkan sebelumnya, penyebaran virus SARS-CoV-2 dari orang ke orang seharusnya terjadi terutama melalui droplet, ketika pasien batuk, bersin, atau bahkan berbicara dan bernyanyi. Droplet biasanya tidak dapat melintasi lebih dari enam kaki (hampir dua meter) dan tetap berada di udara untuk waktu yang terbatas. Namun, droplet virus SARS-CoV-2 tetap utuh dan menular dalam tetesan (diameter $<5$ mikron) dan dapat melayang di udara hingga tiga jam. Oleh karena itu, isolasi udara, ventilasi ruangan, dan aplikasi disinfektan yang sesuai di ruangan dapat membatasi penyebaran virus secara aerosol. ${ }^{3,4}$ Penularan tidak langsung terjadi ketika secara tidak sengaja melakukan kontak dengan benda yang terkontaminasi virus tersebut, kemudian menyentuh daerah di wajah seperti mata, hidung, atau mulut. Oleh karena itu, mencuci tangan dengan sabun ataupun hand sanitizer berbahan dasar alcohol sebelum menyentuh daerah wajah sangatlah penting untuk mengurangi risiko terjangkit. ${ }^{4}$

Demam, batuk kering. dan fatigue merupakan gejala yang paling sering ditemukan pada orang yang terinfeksi dengan virus SARS-CoV-2. Beberapa gejala sindroma saluran napas atas seperti keluar cairan hidung, hidung tersumbat, atau sakit tenggorokan bisa terjadi. Saluran cerna juga bisa dipengaruhi oleh penyakit ini yang menyebabkan rasa tidak nyaman di bagian perut, diare, muntah-muntah, juga intoleransi makanan. Tanda lainnya yang mungkin bisa namun lebih kecil kemungkinannya untuk terjadi ialah sakit kepala, hilangnya indera penciuman dan indera rasa, konjungtivitis, manifestasi di kulit berupa ruam sampai perubahan warna jari bisa terjadi. Telah diketahui bahwa manusia yang terinfeksi dengan virus ini bisa menunjukkan gejala ringan atau asimtomatik. Hal ini dikarenakan manifestasi klinis dari virus ini muncul secara bertahap. ${ }^{5,6}$

Pada anak-anak, diasumsikan lebih kecil kemungkinannya dari orang dewasa untuk terinfeksi dengan COVID-19. Diperkirakan bahwa kurang dari $1 \%$ pasien pediatri berusia $<10$ tahun yang terinfeksi dengan pandemi virus COVID-19, ${ }^{6}$ dan sekitar $2,4 \%$ pada yang berusia $<18$ tahun. ${ }^{5}$ Pada neonatus, gejala yang paling sering ialah demam $(54 \%)$ dan batuk $(33 \%){ }^{7}$ Secara umum, anak-anak dengan infeksi virus COVID-19 mengembangkan bentuk penya- 
kit yang ringan, ${ }^{8}$ tapi neonatus lebih rentan untuk terinfeksi virus SARS-CoV-2 walaupun mortalitas sangat rendah $(0,006 \%) .{ }^{7} \mathrm{Hal}$ ini mungkin dapat dijelaskan oleh fakta bahwa neonatus lebih sering terekspos dengan virus infeksi daripada orang dewasa; hal ini memungkinkan mereka untuk menghadapi virus SARS-CoV-2 lebih efektif. ${ }^{9}$ Teori lain juga menyatakan bahwa gejala penyakit lebih ringan yang terjadi pada anak dikarenakan oleh peran angiotensin-converting enzymes 2 (ACE2), yang merupakan tempat pengikatan untuk virus SARS-CoV2. ACE-2 ini kurang matang pada anak dibandingkan dengan dewasa. Hal ini dikarenakan kekebalan sistem imun pada neonatus belum berkembang sempurna sehingga anak tidak mampu melakukan badai sitokin yang bertanggung jawab atas keparahan penyakit yang terlihat pada dewasa. ${ }^{7}$

Penatalaksanaan neonatus yang positif terinfeksi virus COVID-19 dan asimtomatik ialah isolasi bersama keluarga dan orang terdekat selama 2 minggu. ${ }^{10}$ Pasien yang memiliki gejala simtomatik harus diselidiki apakah telah memiliki tanda bahaya. Pasien yang memiliki gejala ringan dan tidak memiliki tanda bahaya harus juga di isolasi di rumah dengan memberikan konsultasi dan edukasi pada orang tua mengenai pentingnya mengetahui tanda bahaya dan penurunan kesehatan yang mungkin terjadi pada anak dan bayi mereka. Kebanyakan neonatus akan diberikan pengobatan berdasarkan gejala yang timbul dikarenakan belum ada anti virus atau pengobatan yang pasti untuk jenis penyakit ini. Neonatus dengan tanda bahaya, komorbiditas, faktor risiko dan pneumonia berat harus segera dirawat secara khusus di ICU atau bangsal penderita penyakit COVID-19. ${ }^{7,10}$

\section{METODE PENELITIAN}

Penelitian ini merupakan suatu literature review dengan menggunakan beberapa database baik nasional maupun internasional seperti Google Scholar, PubMed, dan Clinicalkey. Kata kunci yang digunakan ialah Covid-19/SARS-CoV-2 AND sign and symptom AND laboratory.

\section{HASIL PENELITIAN}

Setelah melalui tahap seleksi studi, didapatkan 20 literatur yang memenuhi kriteria inklusi dan ekslusi terdiri dari 15 penelitian case report, tiga penelitan retrospective, satu penelitian observational dan satu penelitian cohort.

Tabel 1 memperlihatkan bahwa semua publikasi penelitian ini dilakukan pada tahun 2020. Terdapat delapan penelitian yang dilakukan di Wuhan, China, sedangkan penelitian lainnya dilakukan di Xiamen, China, dan Chongqing, China. Terdapat juga penelitian yang dilakukan di luar China, yaitu di Lima, Peru; Roma, Italia; Zanjan, Iran; Milan, Italia; Seoul, Korea; Bergamo, Italia; Teheran, Iran; Sao Paolo, Brasil; Boston, USA; dan Los Angeles, USA. Jumlah sampel penelitian dalam dua puluh literatur terdiri dari 31 neonatus yang telah terkonfirmasi positif terinfeksi virus SARSCoV-2; 15 di antaranya berjenis kelamin laki-laki, lima berjenis kelamin perempuan, dan sisanya tidak dilaporkan. Usia anak yang diteliti sesuai dengan usia kategori neonatus yakni 0-28 hari.

Tabel 2 membahas gejala klinis pada neonatus yang positif virus SARS-CoV-2. Tabel 3 memperlihatkan pemeriksaan penunjang berupa pemeriksaan laboratorium dan CT Scan pada neonatus virus SARS-CoV-2.

Tabel 1. Jenis penelitian yang dilakukan, lokasi penelitan, serta distribusi dari jumlah dan jenis kelamin sampel dalam 20 penelitian yang dikaji

\begin{tabular}{|c|c|c|c|c|c|c|}
\hline \multirow[t]{2}{*}{ No. } & \multirow[t]{2}{*}{ Author } & \multirow[t]{2}{*}{ Desain Studi } & \multirow[t]{2}{*}{ Tempat Penelitian } & \multicolumn{2}{|c|}{ Jenis Kelamin } & \multirow[t]{2}{*}{$\mathbf{N}$} \\
\hline & & & & Laki-laki & Perempuan & \\
\hline 1. & Zeng et al ${ }^{11}$ & Cohort study & Wuhan, China & 3 & - & 3 \\
\hline 2. & Hong et $\mathrm{al}^{12}$ & $\begin{array}{c}\text { Retrospective } \\
\text { study }\end{array}$ & Xiamen. China & 1 & - & 1 \\
\hline 3. & Alzamora et $\mathrm{al}^{13}$ & Case report & Lima, Peru & NA & NA & 1 \\
\hline 4. & Wang $\mathrm{S}$ et al ${ }^{14}$ & Case report & Wuhan, China & NA & NA & 1 \\
\hline 5. & $\mathrm{Yu}$ et $\mathrm{al}^{15}$ & Retrospective & Wuhan, China & NA & NA & 1 \\
\hline
\end{tabular}




\begin{tabular}{|c|c|c|c|c|c|c|}
\hline 6. & Buonsenso et al ${ }^{16}$ & $\begin{array}{c}\text { study } \\
\text { Observational } \\
\text { study }\end{array}$ & Roma, Italia & NA & NA & 2 \\
\hline 7. & Lu et $\mathrm{al}^{8}$ & Case report & Chongqing, China & NA & NA & 3 \\
\hline 8. & Dong et $\mathrm{al}^{17}$ & Case report & Wuhan, China & - & 1 & 1 \\
\hline $9 .$. & Kamali et al ${ }^{18}$ & Case report & Zanjan, Iran & NA & NA & 1 \\
\hline 10. & Canarutto et a $1^{19}$ & Case report & Milan, Italia & 1 & - & 1 \\
\hline 11. & Han et $\mathrm{al}^{20}$ & Case report & Seoul, Korea & - & 1 & 1 \\
\hline 12. & Wang $\mathrm{J}$ et $\mathrm{al}^{21}$ & Case report & Wuhan, China & NA & NA & 1 \\
\hline 13. & Patane et $\mathrm{al}^{22}$ & Case report & Bergamo, Italia & 1 & 1 & 2 \\
\hline 14. & $\mathrm{Wu}$ et $\mathrm{al}^{23}$ & $\begin{array}{l}\text { Retrospective } \\
\text { study }\end{array}$ & Wuhan, China & - & 2 & 2 \\
\hline 15. & Ying et $\mathrm{al}^{24}$ & Case report & Wuhan, China & NA & NA & 1 \\
\hline 16. & Sagheb et $\mathrm{al}^{25}$ & Case report & Teheran, Iran & 2 & - & 2 \\
\hline 17. & de Carvalho et $\mathrm{al}^{26}$ & Case report & Sao Paolo, Brasil & 1 & - & 1 \\
\hline 18. & Wardell et $\mathrm{al}^{27}$ & Case report & Boston, USA & 4 & - & 4 \\
\hline 19. & Precit et $\mathrm{al}^{28}$ & Case report & Los Angeles, USA & 1 & - & 1 \\
\hline \multirow[t]{2}{*}{20.} & Yan et $\mathrm{al}^{29}$ & Case report & Wuhan, China & 1 & - & 1 \\
\hline & Total & & & 15 & 5 & 31 \\
\hline
\end{tabular}

Tabel 2. Distribusi dan jenis gejala klinis yang dialami oleh 31 neonatus yang terinfeksi dengan virus SARS-CoV-2

\begin{tabular}{|c|c|c|c|c|c|c|c|c|c|c|c|}
\hline No. & Author & Demam & Batuk & $\begin{array}{l}\text { Sesak } \\
\text { Nafas }\end{array}$ & $\begin{array}{c}\text { Muntah / } \\
\text { Feeding } \\
\text { intolerance }\end{array}$ & Diare & Rhinorea & $\begin{array}{c}\text { Ruam } \\
\text { di } \\
\text { Kulit }\end{array}$ & Sianosis & Penumonia & Takikardi \\
\hline 1. & $\begin{array}{l}\text { Zeng.L et } \\
\mathrm{al}(3)^{11}\end{array}$ & $\sqrt{ } \sqrt{ }$ & $\sqrt{ }$ & $\sqrt{ }$ & $\sqrt{ }$ & - & - & - & $\sqrt{ }$ & $\sqrt{\sqrt{ }}$ & - \\
\hline 2. & $\begin{array}{l}\text { Hong et al } \\
\text { (1) }{ }^{12}\end{array}$ & NA & NA & NA & NA & NA & NA & NA & NA & NA & NA \\
\hline 3. & $\begin{array}{l}\text { Alzamora } \\
\text { et al (1) }{ }^{13}\end{array}$ & - & $\checkmark$ & $\sqrt{ }$ & - & - & - & - & - & - & - \\
\hline 4. & $\begin{array}{l}\text { Wang et al } \\
\text { (1) } 14\end{array}$ & - & - & - & - & - & - & - & - & - & - \\
\hline 5. & $\begin{array}{l}\text { Yu et al } \\
\text { (1) }\end{array}$ & - & - & $\sqrt{ }$ & - & - & - & - & - & - & - \\
\hline 6. & $\begin{array}{l}\text { Buonsenso } \\
\text { et al (2) }{ }^{16}\end{array}$ & - & - & - & - & - & - & - & - & - & - \\
\hline 7. & $\begin{array}{l}\text { Lu et al } \\
(3)^{8}\end{array}$ & $\sqrt{\sqrt{ }}$ & $\sqrt{ } \sqrt{ }$ & $\sqrt{ } \sqrt{ }$ & $\sqrt{\sqrt{ }}$ & - & - & - & - & - & - \\
\hline 8. & $\begin{array}{l}\text { Dong et al } \\
\text { (1) } 17\end{array}$ & - & - & - & - & - & - & - & - & - & - \\
\hline 9.. & $\begin{array}{l}\text { Kamali et } \\
\text { al (1) }\end{array}$ & $\sqrt{ }$ & - & $\checkmark$ & - & - & - & $\checkmark$ & - & - & $\sqrt{ }$ \\
\hline 10. & $\begin{array}{l}\text { Canarutto } \\
\text { et al (1) } 19\end{array}$ & $\sqrt{ }$ & $\sqrt{ }$ & - & - & - & $\sqrt{ }$ & - & - & - & - \\
\hline 11. & $\begin{array}{l}\text { Han et al } \\
\text { (1) }\end{array}$ & $\sqrt{ }$ & $\sqrt{ }$ & - & $\sqrt{ }$ & - & $\sqrt{ }$ & - & - & - & $\sqrt{ }$ \\
\hline 12. & $\begin{array}{l}\text { Wang et } \\
\text { al (1) } 21\end{array}$ & $\sqrt{ }$ & $\sqrt{ }$ & - & $\sqrt{ }$ & $\checkmark$ & - & - & - & - & - \\
\hline 13. & $\begin{array}{l}\text { Patane et } \\
\text { al (2) } 22\end{array}$ & - & - & - & $\sqrt{ } \sqrt{ }$ & - & - & - & - & - & - \\
\hline 14. & $\begin{array}{l}\text { Wu et al } \\
\text { (2) }\end{array}$ & $\sqrt{ }$ & - & - & - & - & - & - & - & - & - \\
\hline 15. & $\begin{array}{l}\text { Ying et al } \\
\text { (1) }\end{array}$ & - & - & - & - & - & - & - & - & - & - \\
\hline 16. & $\begin{array}{l}\text { Sagheb et } \\
\text { al (2) } 25\end{array}$ & $\sqrt{ } \sqrt{ }$ & - & $\sqrt{ } \sqrt{ }$ & - & - & - & - & - & - & - \\
\hline 17. & $\begin{array}{c}\text { de } \\
\text { Carvalho } \\
\text { et al (1) }\end{array}$ & $\sqrt{ }$ & - & $\sqrt{ }$ & - & - & - & - & - & - & - \\
\hline 18. & $\begin{array}{l}\text { Wardell et } \\
\text { al (4) } 27\end{array}$ & $\sqrt{ } \sqrt{ } \sqrt{ }$ & $\sqrt{ }$ & $\sqrt{ }$ & $\sqrt{ } \sqrt{ }$ & - & - & - & - & - & $\sqrt{ } \sqrt{ }$ \\
\hline 19. & $\begin{array}{l}\text { Precit et al } \\
\text { (1) } 28\end{array}$ & - & - & $\sqrt{ }$ & $\sqrt{ }$ & - & $\sqrt{ }$ & - & - & - & - \\
\hline 20. & $\begin{array}{l}\text { Yan et al } \\
(1)^{29}\end{array}$ & - & - & - & - & - & - & $\sqrt{ }$ & - & - & - \\
\hline
\end{tabular}


Tabel 3. Distribusi dan hasil dari pemeriksaan radiografi (CT Scan) kepada tiga puluh satu neonatus yang terinfeksi dengan virus SARS-CoV-2

\begin{tabular}{|c|c|c|c|c|c|c|}
\hline No. & Author & $\begin{array}{c}\text { Ground Glass } \\
\text { Opacity (GGO) }\end{array}$ & $\begin{array}{c}\text { Bilateral } \\
\text { GGO }\end{array}$ & $\begin{array}{c}\text { Thickened } \\
\text { Lung Texture }\end{array}$ & $\begin{array}{l}\text { Nodular/Patchy } \\
\text { Shadow }\end{array}$ & Air Bronchogram \\
\hline 1. & $\begin{array}{l}\text { Zeng et al } \\
(3)^{11}\end{array}$ & $\sqrt{\sqrt{ }}$ & - & - & - & - \\
\hline 2. & $\begin{array}{l}\text { Hong et al } \\
(1)^{12}\end{array}$ & NA & NA & NA & NA & NA \\
\hline 3. & $\begin{array}{l}\text { Alzamora et } \\
\text { al (1) }\end{array}$ & - & - & - & - & - \\
\hline 4. & $\begin{array}{l}\text { Wang et al } \\
\text { (1) }\end{array}$ & - & - & $\sqrt{ }$ & $\sqrt{ }$ & - \\
\hline 5. & Yu et al $(1)^{15}$ & $\sqrt{ }$ & - & - & - & - \\
\hline 6. & $\begin{array}{l}\text { Buonsenso et } \\
\text { al }(2)^{16}\end{array}$ & - & - & - & - & - \\
\hline 7. & Lu et $\mathrm{al}(3)^{8}$ & NA & NA & NA & NA & NA \\
\hline 8. & $\begin{array}{l}\text { Dong et al } \\
(1)^{17}\end{array}$ & - & - & - & - & - \\
\hline 9. & $\begin{array}{l}\text { Kamali et al } \\
(1)^{18}\end{array}$ & - & - & - & - & - \\
\hline 10. & $\begin{array}{l}\text { Canarutto et } \\
\text { al }(1)^{19}\end{array}$ & - & - & - & - & - \\
\hline 11. & Han et al $(1)^{20}$ & - & - & - & - & - \\
\hline 12. & $\begin{array}{l}\text { Wang et al } \\
(1)^{21}\end{array}$ & $\sqrt{ }$ & - & $\sqrt{ }$ & $\sqrt{ }$ & - \\
\hline 13. & $\begin{array}{l}\text { Patane et al } \\
(2)^{22}\end{array}$ & - & - & - & - & - \\
\hline 14. & Wu et al (2) 23 & $\sqrt{ } \sqrt{ }$ & - & - & - & - \\
\hline 15. & Ying et al (1) & $\sqrt{ }$ & - & - & $\sqrt{ }$ & - \\
\hline 16. & $\begin{array}{l}\text { Sagheb et al } \\
(2)^{25}\end{array}$ & $\sqrt{ }$ & - & - & - & $\sqrt{ }$ \\
\hline 17. & $\begin{array}{l}\text { de Carvalho } \\
\text { et al }(1)^{26}\end{array}$ & - & - & - & - & - \\
\hline 18. & $\begin{array}{l}\text { Hanna } \\
\text { Wardell et al } \\
(4)^{27}\end{array}$ & - & $\sqrt{ } \sqrt{ }$ & $\sqrt{ }$ & - & - \\
\hline 19. & $\begin{array}{l}\text { Precit et al } \\
(1)^{28}\end{array}$ & - & $\sqrt{ }$ & - & - & - \\
\hline 20. & Yan et al $(1)^{29}$ & - & - & - & - & - \\
\hline
\end{tabular}

Tabel 4. Distribusi dan hasil pemeriksaan laboratorium pada 31 neonatus yang terinfeksi dengan virus SARS-CoV-2

\begin{tabular}{|c|c|c|c|c|c|c|c|c|c|}
\hline No. & Author & $\begin{array}{c}\text { Leukosito } \\
\text { sis }\end{array}$ & $\begin{array}{c}\text { Leuko- } \\
\text { penia }\end{array}$ & $\begin{array}{c}\text { Limfo- } \\
\text { penia }\end{array}$ & $\begin{array}{l}\text { Trombo- } \\
\text { sitopenia }\end{array}$ & $\uparrow \mathbf{P C T}$ & $\uparrow \mathbf{A S T}$ & $\uparrow \mathrm{CK}-\mathrm{MB}$ & $\uparrow$ TBIL \\
\hline 1. & $\begin{array}{l}\text { Zeng et al } \\
(3)^{11}\end{array}$ & $\sqrt{ } \sqrt{ }$ & - & $\sqrt{ } \sqrt{ }$ & $\sqrt{ }$ & $\sqrt{ }$ & $\sqrt{ }$ & $\sqrt{ }$ & $\sqrt{ }$ \\
\hline 2. & $\begin{array}{l}\text { Hong et al } \\
(1)^{12}\end{array}$ & NA & NA & NA & NA & NA & NA & NA & NA \\
\hline 3. & $\begin{array}{l}\text { Alzamra et } \\
\text { al }(1)^{13}\end{array}$ & - & - & - & - & - & - & - & - \\
\hline 4. & $\begin{array}{l}\text { Wang et al } \\
(1)^{14}\end{array}$ & - & - & $\sqrt{ }$ & - & - & $\sqrt{ }$ & $\sqrt{ }$ & $\sqrt{ }$ \\
\hline 5. & Yu et al (1) 15 & NA & NA & NA & NA & NA & NA & NA & NA \\
\hline 6. & $\begin{array}{l}\text { Buonsenso et } \\
\text { al }(2)^{16}\end{array}$ & NA & NA & NA & NA & NA & NA & NA & NA \\
\hline 7. & Lu et al $(3)^{8}$ & NA & NA & NA & NA & NA & NA & NA & NA \\
\hline 8. & $\begin{array}{l}\text { Dong et al } \\
\text { (1) }\end{array}$ & $\sqrt{ }$ & - & - & - & $\sqrt{ }$ & $\sqrt{ }$ & - & $\sqrt{ }$ \\
\hline $9 .$. & $\begin{array}{l}\text { Kamali et al } \\
(1)^{18}\end{array}$ & - & - & $\sqrt{ }$ & - & - & - & - & - \\
\hline 10. & $\begin{array}{l}\text { Canarutto et } \\
\text { al }(1)^{19}\end{array}$ & - & - & $\sqrt{ }$ & - & - & - & - & - \\
\hline 11. & Han et al & - & - & - & - & - & - & - & - \\
\hline
\end{tabular}




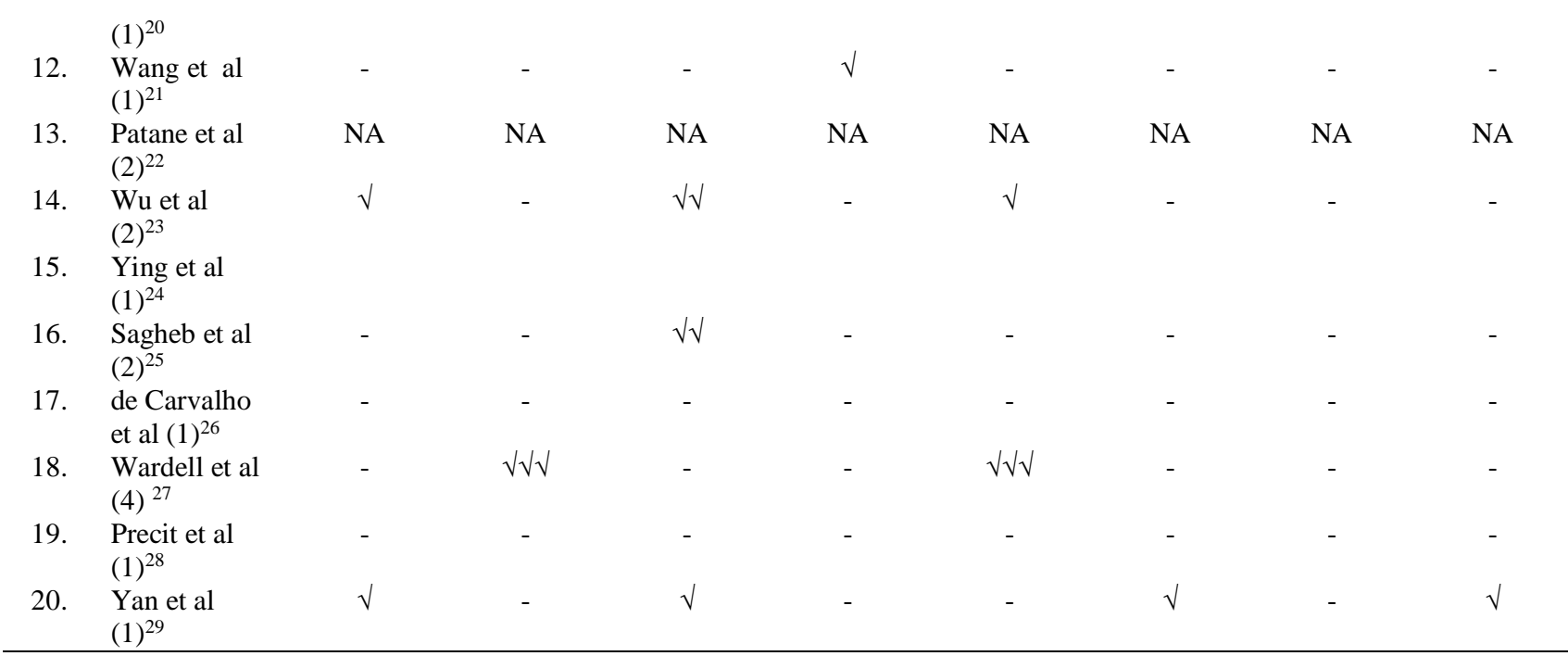

\section{BAHASAN}

Pada penelitian ini terdapat 31 subjek neonatus yang diamati. Demam $>37,5^{\circ} \mathrm{C}$ ialah gejala klinis yang paling sering muncul sebesar 54,8\% (17/31), diikuti oleh sesak nafas 35,4\% (11/31), dan muntah atau feeding intolerance $35,4 \%$ (11/31). Selanjutnya ialah batuk sebesar 29\% (9/31), takikardi $16,1 \%(5 / 31)$, rhinorea $9,7 \%$ (3/31), pneumonia $9,7 \%(3 / 31)$, ruam di kulit $6,5 \%(2 / 31)$, diare $3,2 \%(1 / 31)$, dan sianosis 3,2\% (1/31). Gejala asimtomatik juga bisa terjadi dan ditemukan pada lima neonatus yaitu 16,1\% (5/31)].

Semua literatur yang dikaji, khususnya literatur yang ditulis oleh Hong et al, ${ }^{12}$ tidak melaporkan gejala klinis dari neonatus yang terkonfirmasi positif terinfeksi virus SARSCoV-2. Demam merupakan gejala klinis yang paling sering muncul oleh karena demam merupakan proses alami dari tubuh untuk melawan infeksi baik dari bakteri, virus, dll yang masuk ke tubuh. Oleh karena itu, hampir semua pasien yang terinfeksi virus SARS-CoV-2 mengalami demam. Pada saat demam penyakit COVID-19, terjadi pengeluaran sitokin seperti $\mathrm{TNF} \alpha$, IFN- $\gamma$, IL1, IL4, IL6 untuk memicu imunitas seluler dan imunitas nonspesifik. Selain itu, pada pasien yang terinfeksi dengan virus SARS-CoV-2 bisa terpicu vasculosum of the lamina terminalis (OVLT) di hipotalamus akibat peningkatan tersebut yang menyebabkan meningkatnya sintesis prostaglandin
(PGE2) sehingga suhu tubuh meningkat untuk melawan "musuh" dalam tubuh. ${ }^{30}$

Batuk dapat muncul karena virus SARS-CoV-2 ini menginfeksi mukosa saluran napas, sehingga mengaktifkan respons imun yang akan mengeluarkan sitokin seperti (IL1B, IL1RA, IL7, IL8, IL9, IL10, FGF dasar, GCSF, GMCSF, IFN- $\gamma$, IP10, MCP1, MIP1A, MIP1B, PDGF, TNF $\alpha$ ). Selain itu, virus ini juga menyerang organ yang mengekspresikan angiotensin converting enzyme 2 (ACE2) seperti paru dimana virus ini memasuki paru melalui sel mukosa nasal dan laring, kemudian ke saluran napas dan berakhir di paru. Hal ini akan mengakibatkan peningkatan produksi sputum yang berlebih dan menyebabkan terjadinya penumpukan sekret dan obstruksi jalan napas sehingga terjadi batuk tidak efektif atau kering sampai sesak nafas. ${ }^{30}$

Untuk hasil pemeriksaan radiografi berupa $C T$-Scan, sembilan neonatus menunjukkan gambaran ground glass opacity (GGO) (29\%) dan tiga neonatus lainnya menunjukkan gambaran bilateral GGO $(9,7 \% ; 3 / 31)$. Penebalan tekstur paru ditemukan pada tiga neonatus $(9,7 \%)$ dan bayangan nodular atau patchy stripes juga ditemukan pada tiga dari 31 neonatus terinfeksi SARS-CoV-2 (9,7\%). Gambaran air bronchogram sendiri muncul pada seorang neonatus $(3,2 \%)$. Gambaran normal juga bisa terjadi pada neonatus terinfeksi virus SARS-CoV-2 yaitu ternyata 14 neona- 
tus tidak menunjukan abnormalitas apapun atau normal $(45,2 \%)$. Dari semua literatur yang dikaji, terdapat dua literatur yang tidak menjabarkan hasil radiografi dari neonatus terinfeksi dengan SARS-CoV-2 (6,5\%). Pada pemeriksaan penunjang radiografi khususnya CT-Scan, pasien dengan hasil pencitraan GGO yang paling banyak ditemukan. Pada GGO, alveoli yang seharusnya terisi udara, terisi dengan air sehingga memberikan gambaran berwarna abu-abu. Bila cairan di dalam alveoli terus bertambah, maka gambaran GGO bisa berkembang menjadi konsolidasi yang memberikan gambaran paru putih. Nodul atau patchy stripes akan ditemukan di fase penyembuhan yaitu ketika konsolidasi (GGO) pada paru perlahan-lahan terserap dan membaik.

Pada pemeriksaan laboratorium, dari 31 neonatus terkonfirmasi positif terinfeksi virus SARS-CoV-2, lima neonatus tidak memiliki abnormalitas pemeriksaan laboratorium/normal (16,1\%). Abnormalitas yang muncul dari pemeriksaan laboratorium yang pertama ialah leukositosis pada lima neonatus $(16,1 \%)$ sedangkan leukopenia diamati pada 3 neonatus $(9,7 \%)$, Limfopenia terjadi pada 10 neonatus $(32,2 \%)$ dan trombositopenia pada dua neonatus $(6,5 \%)$. Peningkatan procalcitonin (PCT) diamati pada enam neonatus $(19,3 \%)$, peningkatan aspartat aminotransferase/AST pada empat neonatus $(12,9 \%)$, peningkatan creatinine kinase myocardial band (CKMB) terjadi pada dua neonatus $(6,5 \%)$ dan yang terakhir pada pemeriksan total bilirubin (TBIL) dilaporkan terjadi peningkatan pada empat neonatus $(12,9 \%)$. Namun, dari semua literatur yang dikaji, terdapat lima literatur yang tidak menjabarkan hasil pemeriksaan laboratorium dari neonatus terinfeksi SARSCoV-2 (16,1\%). Dari hasil pengamatan terhadap literatur yang didapat, limfopenia merupakan abnormalitas terbanyak pada hasil pemeriksaan laboratorium. Limfopenia ialah keadaan dimana terjadinya penurunan jumlah limfosit dalam darah, yang dapat membuat tubuh lebih rentan terhadap infeksi virus ataupun bakteri. Pada COVID19, limfopenia diduga terjadi karena peningkatan produksi yang drastis dari sitokin proinflamasi dalam hal ini interleukin-6 (IL-6). Kondisi ini merupakan tanda dari imunitas seluler yang terganggu dan memiliki keterkaitan dengan derajat keparah penyakit dan prognosis dari pasien itu sendiri. Leukositosis juga didapatkan pada penelitian ini. Leukositosis adalah keadaan dimana jumlah leukosit dalam darah meningkat melebihi nilai normal. Hal ini terjadi karena tubuh memoduksi leukosit berlebih untuk melawan virus, bakteri, atau foreign agents yang dapat menyebabkan penyakit, infeksi, atau peradangan. Procalcitonin (PCT) adalah petanda serologik dalam bentuk prohormon dan berfungsi sebagai petanda apabila terjadi infeksi di tubuh kita. PCT juga akan meningkat lebih cepat pada awal infeksi virus atau bakteri dan turun lebih cepat ketika infeksi sudah terkontrol dibandingkan petanda lain seperti CRP sehingga membuat PCT lebih baik dalam menegakkan diagnosis dini dan pengawasan infeksi. ${ }^{31}$

Berdasarkan semua literatur yang telah dikaji didapatkan bahwa tidak semua pasien neonatus yang terkena penyakit COVID-19 menunjukkan gejala klinis atau kelainan pemeriksaan laboratorium dan CT-Scan. Terdapat juga kasus pasien neonatus yang terjangkit COVID-19 dengan gejala klinis asimtomatik atau hanya gejala ringan, pemeriksaan CT-Scan tidak menunjukkan gambaran abnormal, dan pada pemeriksaan laboratorium tidak terdapat perubahan yang bermakna. Cara pasti untuk mengetahuinya ialah dengan melakukan pemeriksaan Real Time Polymerase Chain Reaction (RTPCR) sebagai baku emas untuk mengetahui apakah neonatus tersebut terinfeksi dengan virus SARS-CoV-2 atau tidak. Selain itu, berdasarkan laporan dari semua literatur yang ditinjau, tidak ditemukan kematian dari semua neonatus yang terinfeksi dengan virus SARS-CoV-2 atau karena perburukan penyakitnya.

\section{SIMPULAN}

Gejala klinis yang paling sering muncul pada neonatus terinfeksi COVID-19 ialah demam $>37,5^{\circ} \mathrm{C}$, sesak nafas, muntah dan feeding intolerance, serta batuk, namun 
terdapat juga neonates yang asimtomatik. Pemeriksaan CT-Scan terbanyak menunjukkan gambaran ground glass opacity (GGO), diikuti penebalan tekstur paru dan gambaran nodular (patchy shadow). Pada pemeriksaan laboratorium, abnormalitas yang tersering ialah limfopenia, peningkatan procalcitonin (PCT), dan leukositosis.

Diperlukan penyedian bangsal khusus neonatus atau Neonatal Intensive Care Unit (NICU) untuk merawat pasien neonatus yang terkena penyakit COVID-19 dengan lebih optimal. Keterlibatan semua pihak, baik dari pihak pelayanan kesehatan maupun orang tua terutama ibu sangat dibutuhkan dalam pola asuh dan penanganan neonatus yang positif COVID-19. Diharapkan adanya penelitian lebih lanjut tentang gejala klinis dan pemeriksaan penunjang pada neonatus yang terkena penyakit COVID-19 mengingat masih kurangnya publikasi mengenai penelitian tersebut, khususnya di Indonesia.

\section{Konflik Kepentingan}

Penulis menyatakan tidak terdapat konflik kepentingan dalam studi ini.

\section{DAFTAR PUSTAKA}

1. Pertanyaan jawaban terkait COVID-19 untuk publik [Internet]. [cited 2020 Sep 22]. Available from: https://www.who.int/ indonesia/news/novel-coronavirus/qafor-public

2. WHO. WHO Coronavirus Disease (COVID19) Total Cases [Internet]. 2020. Available from: https://covid19.who.int/

3. COVID-19 STP. Peta sebaran kasus COVID-19 di Indonesia [Internet]. 2020. Available from: https://covid19.go.id/peta-sebaran

4. Lotfi M, Hamblin MR, Rezaei N. COVID-19: Transmission, prevention, and potential therapeutic opportunities. Clin Chim Acta. 2020;508(May):254-66.

5. Seyedi SJ, Shojaeian R, Hiradfar M, Mohammadipour A, Alamdaran SA. Coronavirus disease 2019 (COVID-19) outbreak in pediatrics and the role of pediatricians: A systematic review. Iran J Pediatr. 2020;30(2):1-4.

6. Lee PI, Hu YL, Chen PY, Huang YC, Hsueh PR. Are children less susceptible to COVID-19? J Microbiol Immunol
Infect. 2020;53(3):371-2.

7. Raba AA, Abobaker A, Elgenaidi IS, Daoud A. Novel coronavirus infection (COVID$19)$ in children younger than one year: A systematic review of symptoms, management and outcomes. Acta Paediatr Int J Paediatr. 2020;(June):1948-55.

8. Lu Q, Shi Y. Coronavirus disease (COVID-19) and neonate: What neonatologist need to know. J Med Virol. 2020;92(6):564-7.

9. Ludvigsson JF. Systematic review of COVID19 in children shows milder cases and a better prognosis than adults. Acta Paediatr Int J Paediatr. 2020;109(6): 1088-95.

10. Karimi A, Tabatabaei SR, Rajabnejad M, Pourmoghaddas Z, Rahimi H, Armin S, et al. An algorithmic approach to diagnosis and treatment of coronavirus disease 2019 (COVID-19) in children: Iranian expert's consensus statement. Arch Pediatr Infect Dis. 2020;8(2): e102400.

11. Zeng L. Neonatal early-onset infection with SARS-CoV-2 in 33 neonates born to mothers with COVID-19 in Wuhan, China. JAMA Pediatr. 2020;174(7): 722-5.

12. Hong H, Wang Y, Chung HT, Chen CJ. Clinical characteristics of novel coronavirus disease 2019 (COVID-19) in newborns, infants and children. Pediatr Neonatol. 2020;61(2):131-2.

13. Alzamora MC, Paredes T, Caceres D, Webb CM, Webb CM, Valdez LM, et al. Severe COVID-19 during pregnancy and possible vertical transmission. Am J Perinatol. 2020;37(8):861-5.

14. Wang S, Guo L, Chen L, Liu W, Cao Y, Zhang $\mathrm{J}$, et al. A case report of neonatal 2019 coronavirus disease in China. Clin Infect Dis. 2020;71(15):853-7.

15. Yu N, Li W, Kang Q, Xiong Z, Wang S, Lin $\mathrm{X}$, et al. Clinical features and obstetric and neonatal outcomes of pregnant patients with COVID-19 in Wuhan, China: a retrospective, single-centre, descriptive study. Lancet Infect Dis. 2020;20(5):559-64. Available from: http://dx.doi.org/10.1016/S14733099(20)30176-6

16. Buonsenso D, Costa S, Sanguinetti M, Cattani $\mathrm{P}$, Posteraro B, Marchetti $\mathrm{S}$, et al. Neonatal late onset infection with severe acute respiratory syndrome coronavirus 
2. Am J Perinatol. 2020; 37(8):869-72.

17. Dong L. Possible vertical transmission of SARS-CoV-2 from an infected mother to her newborn. Public Health Ethics. 2017;10(1):49-61.

18. Kamali AM, Jafari N, Eftekhari K. Novel coronavirus in a 15-day-old neonate with clinical signs of sepsis, a case report. Infect Dis (Auckl). 2020;52(6): 427-9. Available from: https://doi.org/ 10.1080/23744235.2020.1747634

19. Canarutto D, Priolo A, Russo G, Pitea M, Vigone MC, Barera G. COVID-19 infection in a paucisymptomatic neonatus: raising the index of suspicion in epidemic settings. Pediatr Pulmonol. 2020;55(6):E4-5. Available from: http://dx.doi.org/10.1002/ppul.24754

20. Han MS, Cho SI, Park SS, Choi EH. Sequential analysis of viral load in a neonate and her mother infected with SARS-CoV-2. :1-13.

21. Jin W, Dan W, Guo-Ce C, Xu-Wei T, LingKong Z. SARS-CoV-2 infection with gastrointestinal symptoms as the first manifestation in a neonate. Chinese $\mathrm{J}$ Contemp Pediatr. 2020;22(3):211-4.

22. Patanè L, Morotti D, Giunta MR, Sigismondi C, Piccoli MG, Frigerio L, et al. Vertical transmission of coronavirus disease 2019: severe acute respiratory syndrome coronavirus 2 RNA on the fetal side of the placenta in pregnancies with coronavirus disease 2019-positive mothers and neonates at birth. Am J Obstet Gynecol MFM. 2020;2(3):100145.

23. Wu YT, Liu J, Xu JJ, Chen YF, Yang W, Chen $\mathrm{Y}$, et al. Neonatal outcome in 29 pregnant women with COVID-19: A retrospective study in Wuhan, China. PLoS Med 2020;17(7):1-19. Available from: http://dx.doi.org/10.1371/journal. pmed.1003195

24. Xiong Y, Zhang Q, Zhao L, Shao J, Zhu W. Clinical and imaging features of COVID-19 in a neonate. Chest. 2020; 158(1):e5-7.

25. Sagheb S, Lamsehchi A, Jafary M, Atef-Yekta $\mathrm{R}$, Sadeghi K. Two seriously ill neonates born to mothers with COVID-19 pneumonia- a case report. Ital J Pediatr. 2020;46(1):1-6.

26. de Carvalho WB, Gibelli MAC, Krebs VLJ, Calil VMLT, Nicolau CM, Johnston C. Neonatal SARS-COV-2 infection. Clinics. 2020;75:1-3.

27. Wardell H, Campbell JI, VanderPluym C, Dixit A. Severe Acute Respiratory Syndrome Coronavirus 2 Infection in Febrile Neonates. J Pediatric Infect Dis Soc. 2020; $(\mathrm{Xx}$ Xxxx):1-6.

28. Precit MR, Yee R, Anand V, Mongkol rattanothai K, Pandey U, Dien Bard J. A Case report of neonatal acute respiratory failure due to severe acute respiratory syndrome coronavirus-2. J Pediatric Infect Dis Soc. 2020;9(3):390-2.

29. Chen Y, Peng H, Wang L, Zhao Y, Zeng L, $\mathrm{Gao} \mathrm{H}$, et al. Infants born to mothers with a new coronavirus (COVID-19). Front Pediatr. 2020;8(March):1-5.

30. Sukmana M, Yuniarti FA. The Pathogenesis Characteristics and symptom of Covid19 in the context of establishing a nursing diagnosis. J Kesehat Pasak Bumi Kalimantan. 2020;3(1):21-8.

31. Husada D, Adnyana IGNT, Setyoningrum RA, Saharso D, Ismoedijanto I. Akurasi diagnostik prokalsitonin sebagai petanda serologis untuk membedakan infeksi bakteri dan infeksi virus pada anak. Sari Pediatr. 2016;13(5):316. 